\title{
ENTRETIEN AVEC SILVIA GHERARDI ET ANTONIO STRATI
}

\section{Yoann Bazin}

ESKA | «Revue internationale de psychosociologie et de gestion des comportements organisationnels »

2021/71 Vol. XXVII | pages 213 à 220

ISSN 2262-8401

DOI 10.3917/rips1.071.0213

Article disponible en ligne à l'adresse :

https://www.cairn.info/revue-internationale-de-psychosociologie-de-gestion-descomportements-organisationnels-2021-71-page-213.htm

Distribution électronique Cairn.info pour ESKA.

(C) ESKA. Tous droits réservés pour tous pays.

La reproduction ou représentation de cet article, notamment par photocopie, n'est autorisée que dans les limites des conditions générales d'utilisation du site ou, le cas échéant, des conditions générales de la licence souscrite par votre établissement. Toute autre reproduction ou représentation, en tout ou partie, sous quelque forme et de quelque manière que ce soit, est interdite sauf accord préalable et écrit de l'éditeur, en dehors des cas prévus par la législation en vigueur en France. Il est précisé que son stockage dans une base de données est également interdit. 


\section{ENTRETIENS}




\title{
Entretien avec Silvia Gherardi et Antonio Strati
}

\author{
Yoann Bazin \\ EM Normandie
}

Question 1 - Antonio, when one looks at your resume, there seems to be as sort of aesthetic turn in the 1990s. Before that, you were writing more about symbolism in work relations. Then, aesthetical themes emerge, leading to your famous 1992 paper in AMR (NdE: Strati, 1992). It then became very influential, a sort of stepping stone for many scholars exploring this dimension in organizations.

Is it really a turn, or was it a more progressive evolution in your thinking? Was there something in particular that triggered a desire to approach things differently?

A. Strati - It is a turn, no doubt. But it was grounded in organizational symbolism and qualitative methods in the study of organization life.

At that time, with Silvia, we were conducting a rather extensive research on the organizational culture of a new structure that was being introduced into the university system in Italy: the department. It didn't exist before, we only had faculties and institutes then. Thus, when the department was introduced in the 1980s, together with Silvia, we conducted a study on the organizational culture of three "new" departments of the same prestigious Italian university.

This was the research context in which the aesthetic turn took place. Speaking with academics from these three departments I felt that aesthetics was important in their working life. They mentioned things like "organizational sublime" or "the magic of organizational space" and so on. Thus, we introduced a novelty in our research and - mainly me - I explored the feelings of academics and technical and administrative staff towards aesthetics.

"Do you do beautiful things?" I began to ask. I was interested in the aesthetics of their working life, the aesthetics of their organizational life, the aesthetics of their passion. It was a rather general question to start thinking and telling, and here and there it worked beautifully.

This research in the academic settings - an organizational world that I was familiar with showed something unexpected. In the organizational cultures of the visual arts department, aesthetics was exclusively concerned with the object of study, that is, the work of art studied. It wasn't about the work of art historians and critics at all. They were doing something useful and not something beautiful. In the education department, aesthetics was excluded to the point that it almost seemed like a sin. In the mathematics department, on the contrary, aesthetics was at the center not only of the mathematician's work, but of organizational culture, of the forms of aggregation of academics and of the power relations between the different aggregations. This was the "unexpected" that I illustrated and discussed in my first essay on aesthetics (NdE: Strati, 1990). It was published in Barry Turner's book, Organizational Symbolism (NdE: Turner, 1990). There were two chapters on aesthetics in that book, Robert Witkin's and mine.

Around the same time, I also conducted extensive research on fine art photography in Europe. Being an art photographer myself, I felt I could explore this world of art by adopting 
the same ethnographic style that we had held when exploring academia by being academics ourselves. With an organizational eye, yes, but attentive to the aesthetic dimension of the world of art photography, as opposed to many researches on art and creative industries which, on the other hand, excluded aesthetics from organizational investigation. So, I explored big events like the Fotokina in Cologne, Germany, or the "Rencontres d'Arles" organized by the Arles National School of Photography in France. I was wondering: why do all these art photographers - famous, less famous, unknown - come together in these great events? What holds them together?

This research highlighted the importance of passion - making photography an art, such as cinema, for example - and of the gratuitousness of organizing an organization that I conceptualized in terms of "organization without walls". I wrote an essay on this organizational concept that I still consider useful for understanding the organization in worlds that could be those of fashion, for example. This essay was published in the first issue of Studies in Cultures, Organizations, and Societies in 1995 (NdE: SCOS, 1995), the journal of the "Standing Conference on Organizational Symbolism", a network of scholars of which I was co-founder and which is still very active (NdE: Lennerfors \& Mitchell, 2019).

At the time, I wanted to keep my two practices of sociology and photography separate. But the aesthetics kept putting them together. To the point that they now often blend together. However, from the very beginning, aesthetics emerged from empirical research. I pointed this out in my book on organizational theory and aesthetic philosophies that Routledge recently published (NdE: Strati, 2019). At the beginning, as I said, I was studying organizational aesthetics from a symbolist point of view and I also wanted to push the boundaries of qualitative research in sociology and organizational theory a little further. And, to go further, I introduced the aesthetic point of view to study organizational life. That is, an "aesthetic style" of doing organizational research, rather than staying within the confines of the study of organizational aesthetics. And it was the mixture of organizational symbolism and organizational aesthetics that formed the background of the aesthetic approach that I then proposed in the issue of AMR / 92 you mentioned.

Question 2 - And was there any resistance when you submitted it? For the first chapter you mentioned, you were within the organizational symbolism community. When you submitted your first academic articles, including the Academy of Management Review one, to more mainstream peer-reviewed journals, what was the reception? Were they intrigued or skeptical? Were there pushbacks? How did the reception feel then?

A. Strati - Well, the article on AMR was for a special issue on new intellectual trends in organizational theory ran by really great editors: Linda Smircich, Marta B. Calás and Gareth Morgan (NdE: Smircich, Calás \& Morgan, 1992). The peer review process was challenging, but in the end the AMR editor-in-chief wrote me a letter telling me that I should be proud of what I have accomplished. I learned then that more than 70 manuscripts had been examined, that is, ten times the number of articles that were subsequently published.

When I said this in my department, they pointed out to me that it would not benefit my career anyway. "That in our system does not count" - I was told - "because it is not a publication in our Italian journals" (Laughs). As if, instead of work, it was a holiday (Laughs). 
Question 3 - A few years later you had a paper in Organization (NdE: Strati, 1996) and another one in Organization Studies (NdE: Strati, 2000) that were specifically about aesthetics. Did you feel that the perspective was slowly being recognized by the mid- and late 1990s as a legitimate approach? Did you feel that you had to go through a lot of editorial pushbacks and negotiations in order to be recognized, accepted and published?

A. Strati - There was a wider process going on during the 1990s, an aesthetic turn in the study of organizational life. And my writings have become a point of reference for scholars interested in that perspective. But you have to consider that we also had seminars, workshops, conferences, and also a small academic network - AACORN - and an online journal, Organizational Aesthetics (NdE: https://oa.journals.publicknowledgeproject.org/).

In those days, an important book was also published which became very influential: Pasquale Gagliardi's Symbols and artifacts (NdE: Gagliardi, 1990). This book was the result of a long process of work in the community of organizational symbolism, and it took shape around a few workshops and during a conference in Milan on the topic of artefacts.

Part of the aesthetic turn came out of a few workshops and smaller conferences, often organized by scholars from the organizational symbolism. Heather Höpfl and Stephen Linstead were very influential in these networks and there was a growing attention to the aesthetic approach. They edited a very important book on the aesthetic of organization (NdE: Linstead and Höpfl, 2000).

Publications followed, as this kind of sensibility was emerging in the 1990s. Then, Sage asked me to write a book. You know, publishing houses came to these conferences to see what was new. When they offered me to write a book on aesthetics, I thought, "This is absolutely crazy. I'll never be able to do it". But in the end, a few months later, I accepted. I didn't think it would become a classic (NdE: Organization and Aesthetics (Strati, 1999)). I only realized this several years later.

Question 4 - Early on, you both had this interest in organizational texture (Gherardi \& Strati, 1990). Silvia, I feel like, although you were not referring to aesthetics in the same sense, your exploration of learning strongly relates to this approach. You don't necessarily refer to it as such, but there's a lot of aesthetics and corporeality in your work (NdE: Gherardi et al., 2013). How important was all this movement in the 1990s that Antonio just described for you? Did it have a direct influence on your work on organizational learning?

S. Gherardi - Absolutely. You're right on both things: that my understanding of aesthetics originates from the fact that knowledge comes through the senses, and the importance of the body, of embodiment, is linked to corporeal knowledge and ethics. Of course, coming from feminism, embodiment and power were at central stage for me. So, the idea that we know through the body, that knowledge is embodied, is the way that I understand aesthetics in a sense closer to my sensibility to the positioning of the researchers in their research practices. Hence, I pursued my interest in aesthetics experimenting with affective ethnography (NdE; Gherardi, 2019) as a style of being in the field and becoming-with others. So, I studied learning, knowing and participating in practices with the idea of sensible knowledge: How knowledge is kept into the body, but also how we know through the senses and are affected by what we do in doing fieldwork. 
Question 5 - And what was the reception of this approach outside of the organizational symbolism community? Was it somehow in the Zeigeist, was it being recognized, or did you feel some resistance in the reception of these ideas?

S. Gherardi - Well, in a sense from my side it was easier because the academic interest in learning and knowing is shared with the other big communities, educational scholars for example, and the OLKC (Organizational Learning, Knowing and Capabilities) network of researchers in which I was active since its beginning at the end of the $90 \mathrm{~s}$.

In organizational studies the idea of learning is not limited to the acquisition of knowledge, it is more a sort of a metaphor. It has to do not with individuals, but with collectives that can do something together since knowledge is a collective activity. We call this social learning: how practitioners participate with competence to the practice at hand. My understanding of learning has always been metaphorical. Most often, I use learning and knowing to theorize that there are no boundaries between the one and the other. To me, in knowing there is already learning, and in learning there is participation in a practice. In the end I conflate the two terms together.

Question 6 - It feels like at some point there was an actual turn, that all this work in the 1990 s and early 2000s slowly became legitimized. How do you feel about this institutionalization of the aesthetic approach? Do you think that we are now at a satisfactory level of acceptance of corporeality and aesthetics? Or are there things that have not been explored and that we should take a look at?

S. Gherardi - Well, it's difficult to give you an answer, because the approaches to corporeality are so different. Some scholars just claim that the body is important, but stay at a discursive level without really engaging with materiality. So, what is really important in the end is that matter matters. With the 2000s I experienced an opening of the feminist debate towards different epistemologies, the de-centering of the subject, the entanglement of subject and object, the material and the discursive and what has been called ethico-onto-epistemology. The turn to practice and the turn to affect are part of this debate.

In a sense, this is just a continuation of the works of Merleau-Ponty, Loïc Wacquant and corporeal sociology. But, at the same time, there is something that goes deeper, for example with Karen Barad and feminist new materialism (NdE: Barad, 2003). Slowly there is a turn toward post-humanism (NdE: Braidotti, 2013) and post-anthropocentric research practices.

Question 7 - What about you, Antonio, with aesthetics? Do you feel like there has been a satisfactory exploration of the approach over the past two decades? Or are there some blind spots that that we could still explore?

A. Strati - Well, there has been an institutionalization, which was unexpected. To me in particular this was completely unexpected. I have had a similar experience with organizational symbolism. I did not expect this at the beginning, in the early 1980s, when we proposed the organizational symbolism approach. Now the network around this topic is alive, there is a journal - Culture $\mathcal{E}$ Organization - it is unbelievable how far it has gone! 
As for the aesthetic approach, the moment I really felt it had been institutionalized was when David Buchanan asked me to write a chapter on the aesthetic approach in the Handbook of organizational research methods (NdE: Buchanan \& Bryman, 2009)

Writing the chapter meant institutionalizing the conceptualization of a study methodology, a method I had illustrated and discussed in the book published by Sage (NdE: Strati, 1999) mentioned above. Indeed, when we study organizational life, it is important to feel the senses, pay attention to what we see, look carefully and smell, touch. So, we need to improve our ability to observe and to listen, not only to the words, to understand the meaning, the symbolism of these words, but also how these words are offered. There is an aesthetic to these sounds and these rhythms, to what we see and what we touch, to what we smell.

What also surprises me are the "blind spots" you were saying. They show that the institutionalization of the aesthetic study of organizational life remains fragmented. It still strikes me, in fact, that organization scholars forget aesthetic methodological awareness. Although we can study organizational life by adopting many different approaches, if we want to understand it, we cannot avoid understanding its aesthetics. This strikes me even more when the organizations studied operate in sectors or areas marked by aesthetics - such as fashion or design - and the organizational study is carried out without paying attention to aesthetics.

Question 8-Antonio, in many of your articles I found hints and references to connections between aesthetics and ethics. In some of your writings they seem to be profoundly interconnected, but I haven't found a more in-depth examination of the relationship between the two. Do you think there can be one without the other? Or are they two fundamentally sides of the same coin?

A. Strati - No, you cannot do one without the other. I stressed this by recently writing on responsible management (NdE: Strati, 2020). When Oliver Laasch and his colleagues invited me to write a chapter (NdE: Laasch et al., 2020), they asked me to write on this link between aesthetics and ethics.

In this chapter on the beauty of responsible management I say that there is always a bond there, that they are interconnected in a very profound way. However, in my writings I always insist on aesthetics because I don't want to see it overwhelmed by ethics. This is what happens in philosophy, in sociology, in all the social sciences: ethics, even under the guise of the useful, dominates everything.

Aesthetics and ethics are closely intertwined. It is impossible to fully understand the beauty of Picasso's Guernica painting without considering that it was a scream against the war and the massacre happening in Spain. The value of ethics, in a certain sense, almost suffocates the aesthetics of the painting. As long as you are not in the presence of the painting. I still remember when I first saw it at the Metropolitan Museum in New York in the 1980s, exiting the elevator and entering the hall: it was enormous, dazzling, fantastic! Aesthetically, I mean.

I want to keep the aesthetics, which is my being in the world of organizational theory, my field, my sensitivity, in a way that is safe from ethics. Hence the beauty of responsible management. It's a nice chapter about an Italian entrepreneur, Olivetti, who did a beautiful thing with his managing. In this company, they were inventing products and working styles, but also innovating and finding new markets, while involving scholars, researchers, artists and designers. That's the beauty of the humanist manager. 
Question 9 - Silvia, in a similar but different way, you've touched upon both aesthetics and ethics. You have explored practice as a concept extensively, but also worked on gender and on care. These notions have a political dimension - in the noble sense of the term. Are practices inherently political? Does that also mean that within organizations, practices always have a kind of corporate politics and power plays dimensions that are built in them?

S. Gherardi - Of course. Because looking at practices is not only looking at the carrying of the practice. There is always another level. Inquiring into a practice means looking at what the consequences are, what the effects of the practice are and how they could be practiced otherwise. So, the political dimension is always there because studying work practices is not only about understanding what is done in a situated way, but also which are the effects of these practices.

Question 10 - And from a methodological point of view, I feel like this question of power and politics are a bit under-explored in the study of practices. Are you of the same opinion?

S. Gherardi - Not at all. I would say that this is the refrain, in a Deleuzian sense, that power is under-explored in practice-based studies. But I don't think that it is the case. When you look at a practice as an agencement, how the elements in a practice are entangled, this is actually the work of power. So actually, every time you look at practice you look at power because you can see how the entanglement is done, what is in and what is left out, what is discarded, marginalized and so on and so on. So, I don't buy this 'power left out' narrative. I think that this is more a projection, an arrière-pensée, that in looking at practices power is not considered. Or, it is said in relation to a restricted view of practice as simple 'what people do'.

Question 11 - In my view, it is indeed there by definition when you look at practice. However, I do feel that many studies on practices that I read don't necessarily pick up on it. It can be in their accounts of the situations and the practices, but sometimes it seems downplayed somehow. But, as you said, that might be a projection on my end.

Anyway, what's next for you? What do you want to explore in the next few years? Or are you finally going to rest and enjoy your retirement? Put it differently: What would you recommend to a PhD student?

A. Strati - One thing I have always encouraged my $\mathrm{PhD}$ students in the past was to have courage. You need to have the courage to do research, the courage to be reflective on your own style of doing research, to pursue your desires, to explore your passions, to experiment with new ways of understanding.

What I liked, for example, with my book 20 years ago (NdE: Strati, 1999), was that I attempted to create an approach to the study of organizational life that didn't exist, at least in those terms that fascinated me. But when I say create, I don't mean to create from nothing. I intend "to give a form". And this requires having the courage to reflect deeply on the writings of some philosophers and some important scholars of social theory. It is something related to the personal taste of the scholar. So, my favorite philosophers, sociologists, economists, are not exactly the same as the ones for Pierre Guillet de Monthoux, for example. Pierre is another important scholar in this field of aesthetics, with whom we not only have a great friendship, but with whom we discuss deeply, we argue endlessly. 
I am very grateful to the younger generation of researchers as they try to deconstruct important aspects of my research. I like it when scholars and students engage in the discussion of this or that aspect. What I really love is when they explore things I haven't seen.

Even in my latest book, Organizational theory and aesthetic philosophies (NdE: Strati, 2019), when I look back to forty years ago, at the end of the 1970s, I see how it was almost "forbidden" to do research that was not mainstream. It took the courage to collectively question the mainstream, to return to studying theorists that were not fashion, but important, to innovate in the field of organizational study.

S. Gherardi - My recommendation is to look not only for the 'what' (of their study), but also the how. The freedom that they have in inventing, in creating and practicing new methods.

A. Strati - With Silvia we have published a chapter in a book on competence (NdE: Gherardi \& Strati, 2017). In this, we did something new, which was to put together some of my photographs - some "photopoems" - within the text. Each section, therefore, has a photograph at the beginning, on an entire page. It is an "interlude", but it is also the starting point for the topics presented in the new section.

It was a way to combine totally visual language and written words together. The aesthetic experience of the visual becomes part of the reading of the text. Something new in academic writing work.

Question 12 - I remember reading this and feeling both disrupted and stimulated by these photographs. They jumped in front of my eyes and sometimes caught my attention to the point that I'd end up day-dreaming about them... instead of doing proper academic work!

Thank you very much to both of you.

\section{REFERENCES}

Barad, K. (2003). Posthumanist performativity: Toward an understanding of how matter comes to matter. Signs: Fournal of women in culture and society, 28(3), 801-831.

Braidotti, R. (2013). The posthuman. Cambridge, UK: Polity Press.

Buchanan, D., \& Bryman, A. (Eds.). (2009). The Sage handbook of organizational research methods. Sage.

Gagliardi, P. (Ed.). (1990). Symbols and artifacts:Views of the corporate landscape. de Gruyter.

Gherardi S (2019) Theorizing affective ethnography for organization studies. Organization 26(6): 741-760.

Gherardi, S., \& Strati, A. (1990). The 'texture' of organizing in an Italian university department. Fournal of Management Studies, 27(6), 605-618.

Gherardi, S., \& Strati, A. (2017). Talking about competence: That "something" which exceeds the speaking subject. In Sandberg, J., Rouleau, L., Langley, A. \& Tsoukas, H. (Eds.), Skillful Performance: Enacting Capabilities, Knowledge, Competence, and Expertise in Organizations. Oxford University Press, pp. 103-124. 
Gherardi, S., Meriläinen, S., Strati, A., \& Valtonen, A. (2013). A practice-based view on the body, senses and knowing in organizations. Editors' introduction. Scandinavian fournal of Management, 29(4), 333-337.

Laasch, O., Suddaby, R., Freeman, R. E., \& Jamali, D. (Eds.). (2020). Research handbook of responsible management. Edward Elgar Publishing.

Lennerfors, T. T. \& Mitchell, L. (Eds.). (2019). SCOS: Searching collectively for our soul. Editoriale Scientifica. ( http://www.scos.org/scos/)

Linstead, S. \& Höpfl, H. (eds.). (2000). The Aesthetic of Organization. Sage.

Smircich, L., Calás, M. B., \& Morgan, G. (1992). Afterward/after words: Open (ing?) spaces. Academy of Management Review, 17(3), 607-611.

Strati, A. (1990) Aesthetics and Organizational Skill. In Turner (1990) Organizational symbolism, pp. 207-224.

Strati, A. (1992). Aesthetic understanding of organizational life. Academy of Management Review, 17(3), 568-581.

Strati A. (1995). Aesthetics and Organizations without Walls. Studies in Cultures, Organizations and Societies, 1(1), 83-105.

Strati, A. (1996). Organizations viewed through the lens of aesthetics. Organization, 3(2), 209218.

Strati, A. (1999). Organization and aesthetics. Sage.

Strati, A. (2000). Putting people in the picture: Art and aesthetics in photography and in understanding organizational life. Organization Studies, 20(7), 53-69.

Strati, A. (2019). Organizational theory and aesthetic philosophies. Routledge.

Strati, A. (2020). Beauty of responsible management: The lens and methodology of organizational aesthetics. In Research Handbook of Responsible Management. Edward Elgar Publishing, pp. 410-419.

Turner, B. A. (Ed.). (1990). Organizational symbolism. de Gruyter.

Witkin, R. (1990) The Collusive Manoeuvre: A Study of Organizational Style in Work Relations. In Turner (1990) Organizational symbolism, pp. 191-206. 